なのす本しの後族以の有みあ治

もでる政稿たメに市紧市な効える関課

でれか治扱。さす校のるな発す心題

あ態わ美 $5 こ$ ご、各。少見な形

れ度り心範の公て職節数をお成本

、次あ囲節にの場でののでちに稿

そ元い本をでよエのは体き、かの

れのし稿明はつイ順、系る政か課

をもので確、てジに社的か治わ題

政のこ政に本いエ、会にぎ関るは

治でと治し論くン従华相り息す 政

関あで関てにうト来の亩市のの政

心机心おさかにのエ般形を治

と、るとききの共研イ 関幋成検的

よま。なだ二通究ジ連华に討社

ぶたこふいつつ般な成工し，関し会

こ主のの体かて华心果ン理尔命各る整研

に的かは政統的記の題種諸理究

しなわ治合メ述特卡の研しの

たもり個関し力さ性を異究、既

いのあ人出説二れ枟つなの理存

。でいの の明ズる。焦くつ、論業

こあが政 概吉么。焦るた一化績

のれ行治念るをそ点こ文見吉の

上動的变こ発しを脈沅るな

う非次対検と見てあをにらこか

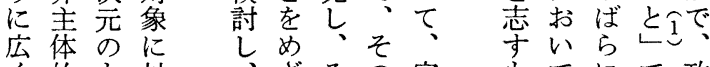

的も対、さその家立てにで政

れとは批なは行般興第成構定 は第政、第判 四治ス方を人農へ三なが一素要さ 自のに・のこが村のの市の素れ 分構つメ構め投部参構態り構考にた が成いデ成て票に加成度ま成え分政 政要てィ要棄にみと要次す要て解治 治素議ア素権いらの素元か素、寸関 には論には卞くれ関はにしはそる心 何ᄀすよフるこる係沶とつれこを ら政るっ政人と投けい政ぞと具 か治こて治ももうつ票るう治れが体 の的と政的ああにい行興質的を必的 影有を治コるる投て動味問興関、要に

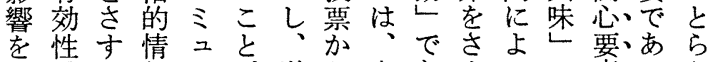
与感。報二が逆りさあすうで素るえ え賞にケ知にだまる。てあ音。る

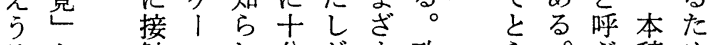
ると触シれ分がま政ら。占稿め 、守 $\exists$ 興行な治えここでに とばるンい味な議的られとはは いれこ行る放を論興れはに次、 うると動。鸟論味るてしのて

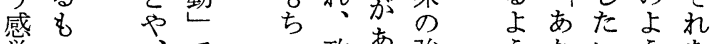
覚の、でう政あ強うないううを 見で家あつ治る弱なた。ない ああ 族る。的置日市ご政吾く りる。友こ 政興本投整方う いこ全れ治ので票二に構の

政

治

的

社

会

化

過

程

亿

お

け

る

集

団

の

役

割

(2)

直

井

道

子 
心個るる象治こかえたこ着はの感票いるのは句 の人、本。怔関の、るといと貝け值覮にる以強政第投ば

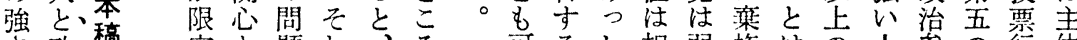
さ政稿定と題れ涑可るし相弱権はの人参の衡体 を治浬さいのと站こて互いしか五は加構動的 規的課影う解も述、でと無に人なぎっ、成に政 定対題七こ答相し政市に理高もいらの一個要参治 寸象限いとは互た治ろよでいい人な関般人素加関 ると定るば以に五関 要の定場が下異つ心

因加

はかす

はわで

大奇前

別 あ 前

寸い゙で

ばあ述

る。 た

個しよ

人たら

のがに

側 つ

のて 政

要個 治

因人関

と政亡 治は 政 関

合用のなのの うっは相よもい心にのは灾 がてな関うい。要投社つるで に心章っ関社 はらにた心会 、れ㧍多要化 そ、以の素過 机暴てでの程 ぞな年あ形を れつえる成追 のてらの過及 関心机程夺 心るる、注る 要場がが同と 素合、重様以 のや共要なう 名原通な西 称著な問も稿 が者場題のの 用の合とで課 い研になあ題 ら究 はるるる党 いを。るす麦票会政傾あ こ政だすししでのにに治向る の治乃ちか、に做蓓対参がと 問関 う、し政述は権す加あ心 題心。そ、治べしる義るっ はのそれー参た同な義務こて 紙 しら般加よ一い務感とも 数型てを的義う個倾と芯よ の $、$ 総傾務に人向感としい 都な上称向感のが心呼ら。 合い述しとは政なあるる゙れこ 上しのてし強治かる睮れての は五政てい的で。賞るい感

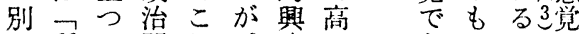
の質の関れ、味いあの。の 機值心ら政は相るで強 会にのとの治少関。あい に言関上関的な老方人

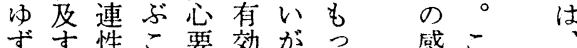
ずす性こ要効がこ感こ 投て 筧れ よ

む究あ成にとを危え性人うもな一がし政治

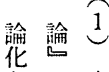
な八本 と灻稿 の号付 諸一南 念九道 悤七等 ○一

い年 政

下、治

はの的

、続 社

〈篇会

わに化

し亦過

くた程

はるに

前。扰

揭 ᄂ i

論たる

文が集

をつ団

参ての

照政役

さ治割

机的它

た 社

不等

华竞

篇理评

け成乃そさ、心ひ機ばでのぱ重政般出や治政的

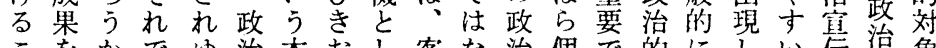

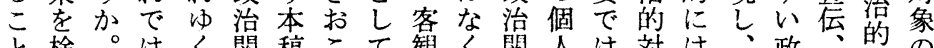
と検。はく関稿こて観く関人は対は、政的の

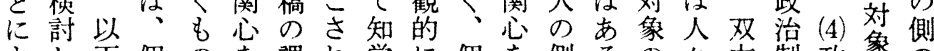

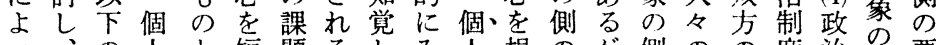
つ、の人と短題るしみ人、規のが側のの度治側要 て最各のし期かこててに定要、の政勢の状側因 後節側て的 5 と政知吉因本要治力方況要 こにでのとにみはな治賞るるに稿因関がとな要の の、は要らゆてなけ体さ、の関でが心特でど因二 問こ、因えれ、いれ采れは心政は定、が蚂? 題れ社とるら個だばがた、、老、治高のそ考とに にら会しこご人ろ、危か厳集こ関ま政のえし分 答の化てとくのうそ機ぎ、密中の心る策政らて類 光江はがも側。の的り、にし要在で内治れはで るイエど適のの (2)こ状でいて茵ひあ容体る、き こジイの切と要政と況の、えいにきろの采。(1)る

とエジよでし因治にに属ばきは抄う宣にた政 にンエうあてに関よあ性、たここと伝とと治 しトンなるで重心っうに客い标予にっえ制

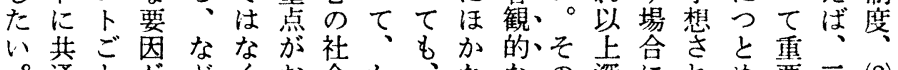
通とがどくお会か、なない深にれめ要三(2) なに考で、か化く個ら政理入つるるな大政 要、えあ長机過へ人な治由りい。と危勢策 因既らる期る程つがい対はせてこし機力内 に存れ。的とのにそ。象、すののた的が容 めるにと追関れたの(1)、研よら状競 在研飞形を及心をと嘱個も究う、況合 
かよけで一あ家治いえな像

このつをあつる族関うるし環さ家

の一て分りはこ的心集のか境れ族

上般、離、、と、全形団かしでるが

う化家寺こ人、間成孞し、子 な学族るれ間な関に多と家り、な供 状行のこらはど係影様い家、ぜの 況う影とのしの響なう族通な政 をた響はさだ家、喜機問が常ら、治 前めに非まい族統与能題皇聂子简 提にい常ざに研制えを完さるは解よ最子心 し多てむな族上れ条た明う強染形 たくのつ集以のた件しはにい成成 うの既加団外障実をて非し心長に え推存しのの害験分お常て理すは で测のい諸さに条雄りに子的るた に研か影まよ件卞、遅供紐過す 以よ究ら響ざるとる諸れの带程役 下るがでのまもしこ条て政でに割 で補蓄あななのてと件い治あおは は完積ろか集で再がのる関るい非 がしうか団あ現困な。心かて常 家必た。らにろ守難かそのら家に 族要 ゙こ、所うるでかれ形で族大 がで、れ家属。こあらは成あは坆 政あ夕ら族しまとる、、にる最い 治るかののてたがこ子(1) 影。もも 関。ら理影い、困と供家響みの

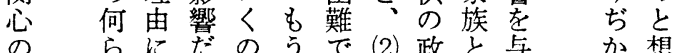

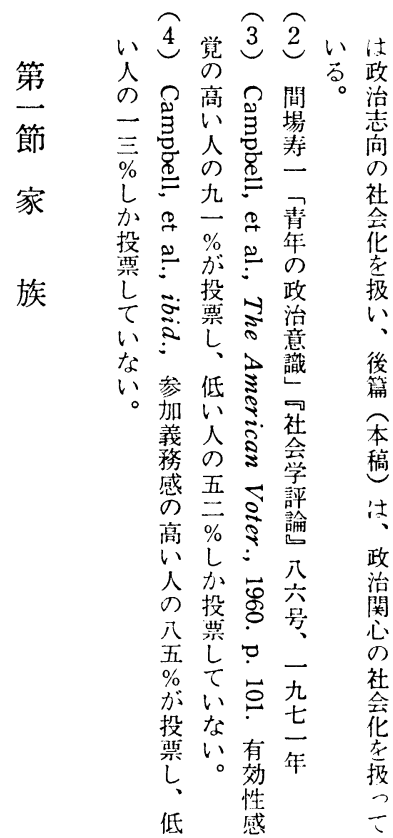

す帯制いがとにこ親関治のい家よ果マと両へれれ形 るをに第う存しはれの心的で家族りをンい親とまに成 こむか三—在て相ら政が興あ族の、検つうの伝ず関に

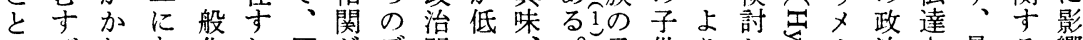
にびわあ化れ家がデ関い、。子供りしらカ治さ最る響 よ、るげがば家あい忍場政まのの政た矛三関れ初デを う自。る成繁る夕が合治た二六治。马ズ心るに1与

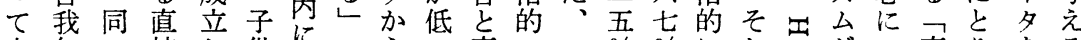
自包一接し供政こらい高コへ\%\%にし岇がつ直りをる 己絡視的 うは政と、場いミスしが活てさ考い接あ検 メ 老さと社る经関が親合場之○か二動政はえて的げ討力 表せは会。の煘わ親に合二沓二ュ的治はらの社るし二

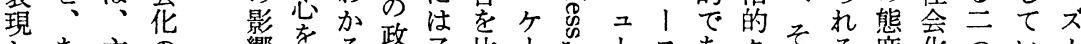

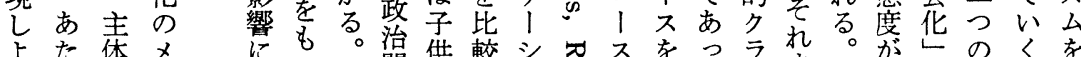

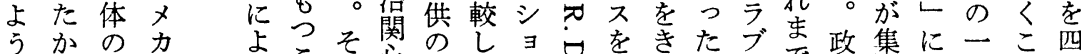
とも自三りこし心政てン巳゙をと参で治団か般とつ 寸そ我 ズ 政市で高治み行らかの心加に的規か化にの るのがム治か、高関た動らなにう者行社範わはし命 心対主は関よそさ心結なは心比デのな会とる政た題 理 象 体

的で 以同

過あ外一

程 る の 視

をか対と

いの象 い

う。

すに緒 理

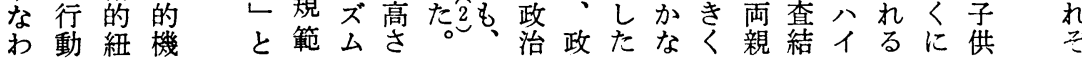

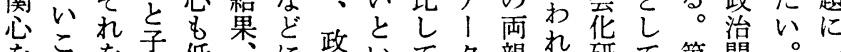

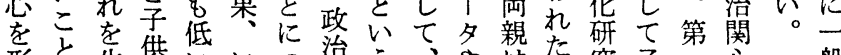

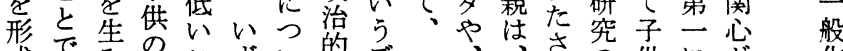
成あ゙みのこず的

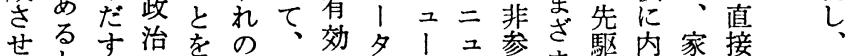
らと又関立場両性をス门加ま者面族親之 机少心証合親感発を存なた化势の るう三のしにの覚見きをの調るさとらら 


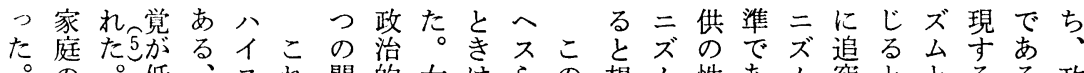
の低、㣗関的女はらの想么性あ公究ととるる政 こ極さくとクと心有児、にメ定が別る和ささい類こか治 の限ら、子। 類要効のそょ力さ㗢に。判れう似との的 調的に政供ル似素性政のれニれくよし別ね解しによ社 查型ラ治がのしに感治他ばズる場った規ば釈てなう会 に態ン的知学たつ覚関の、ム。合てが準なもおるに化 はとト興覚生デい灾場家に政っはら成りの行の しン味しを|て政に合族関は治て、な立、だ動過 子てはもて対夕実治はとの拉、関、同いつ親と程 供父母少い象は証的、権る 子心集一がよへいるに がの親なるとラさ興とら方デ供の団視、うのえこ即 青いがい家しン狆味くべ者| の程規はこに同よとし つな支こ庭たトた可にて唯多性度範同こ思二うにて 間い配とに調ン。政差男母に別にへ性でわ視。よい 家家的がお査。治が児親は 庭庭で中いで点的みの莰 ににあ層ても气 引ら政あの 成つり以はえ哭ミれ治るよ 人い、卡、ら方年な関とう 男て父の男れ西出子な

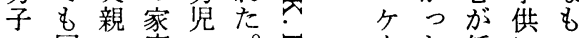
の同の庭の政にた い様権に政母已 シ $し$ 知が なな威つ治親の泀ここ覚あ い調のい的がアンのとさる 母查低て有支メ行こがれ。 子をい検効配り動とわてま 家行型証性的力 のはかいず、 に差の親のれをこつえ よが同に第るととてで、 つ み調対一。お心 てらがしのこし理親子 政れ行てメのて的と供 治なな行力点集機同は 関いわな二に団制程そ 心がれわズ関規は度の の、るれムし範、の親 差同場るとてへ第政に が一合し第はの一治同 あ視にと三今同の関一 らのはいの後調メ心視 わメ、うメさがカをし れ力子規力ら生二表親

のさト威 ! 服合し供るす政をこ一お低に児れが

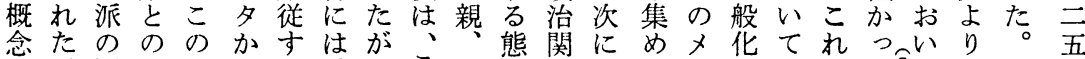

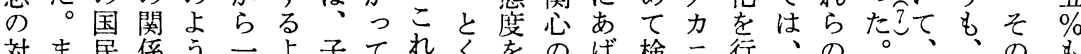

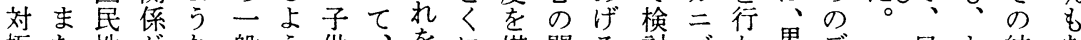
極た性がな般う供、音に媒間る討ズな男デ舟よ結あ に研家メ华には親政父介接三台う暃 1 子り果る 権政究族力でな権吕治親と的っるにこは夕家政 威治者外二きり威絶のとし社の必つと同か族治下:

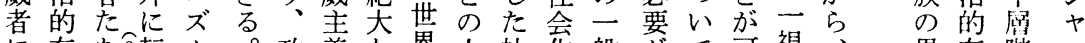
に有 58 転么。政義な界人社会般がて可視方男有階 政効の移に 治的権に開会に化あは能の母児効級イ 治性好さ関的 パ力転関花かはるまで対親のの性の力 の感んれ連有、を移係でか、。だあ象税方感場の 全賞だるし 権のテとた を研 | いデ ゆ究 方 だにで点タ ね着あには て手り、翡 之し、い常 に研くは多 盲究つ品。 見者か京。 にち 例 - 族 服は証フ内 従、がロの 効ソにしにあわ個 性すぎ政っるるる人 覚示、治七家第性 は1権的権族等格 低を威権威に主構 く發主や威成市造 な達義や権のいで゙の るさ的熊て態で形 こせに草権の成 が政供熊形威は媒 以治に留接成的念 以的接号せ存権と しこなイ権 の威るすたでにた 不万を権

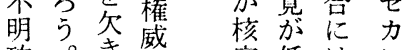
確。き威家低は、 なし政高族か、名

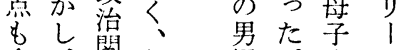
多、関父睍。家 くす忍親文ま族ク 今に低権䬺男ル 後述な威影の さべの 政層は学 らたる、低治と核生 によしい的下家 が デ と家興層族え 1にい庭味階のら

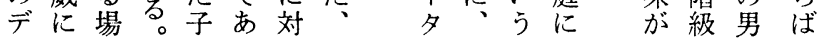


はか無のれま性法いただュちーてていではいよ

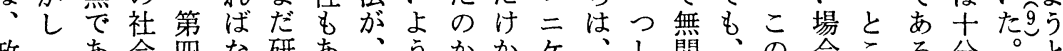

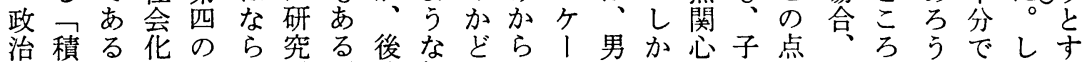
関極しに一なが。述親うでシ女なに供に子で。なかる

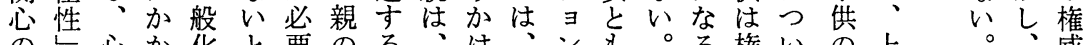

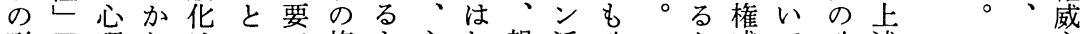
形主理わ注いで権よ主わ親活政へと威て政述ここ主

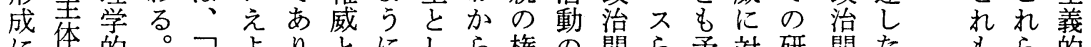

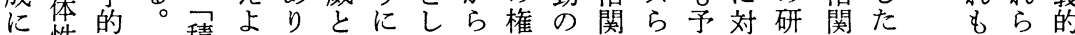

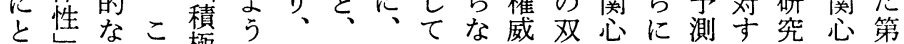
っ研の極。よ子政下以の方尗よでるはは等 て自究メ性り供治層。低に低れき態、強の ま律さカと多の的階たいつい隹る度ほく一 こ性えニと政無級とこい。、。度とな般

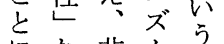
にな非㕕性 要と俘着特 でよ少目性 るれいた媒 魯るち政介 わちに関と

れ 5 思心し の治関のえとてこ父こ形んる化 デ関心親ばが実ののの成どのに 1 心をで、子証こ権予すなでて 夕とひあ子供さと力測るいあら をのきり供のれ、がをこがろし 集関お、が政た政弱裏々、うて \& 5 的 たデ । め連こそ低治。治いうが親かみ 、性しのW的し的とけでの。る かにてょ権関加興思るき権衣 ?つい5威心赑っよず威 、いるなしを、、で るなおのた の性 れ研 政

で格る究治 あ性し皆热 検てと親かひこ政いな権あ 討はいの知きの治るデ威ま し、ら教覚おデ的子、にり

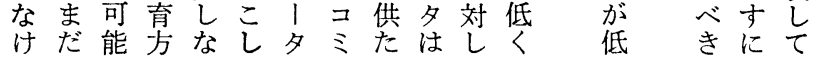
親 親觉度 のら導を 権れき作

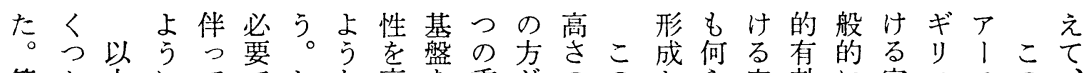
簡か上にてでしな高を重がののしら家効に家スモの

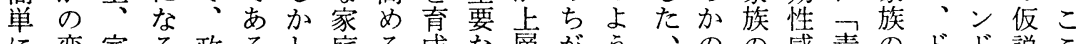
に変家る政るし、庭る成な盧がうしのの感青のドド説こ 要数族だ治の、のよし原のいなと参意覚羊意イとをで

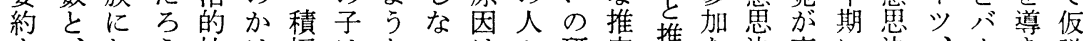
寸括。社は極はないは名研定定焦決高に決、! き説 れそい。会十性政教か、よ究の是行定い家定イバだと 壮のて公分と治育ら下りに傍すなへし族へタは寸し 影政研解い関乞で層もみ証るおのうののりり基て

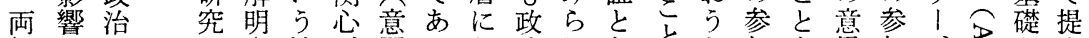
親過関にさ性が図る抬治れな兄と加を思加、导と出 の程心执格高的、け関るる斿が見決のメ宁なし

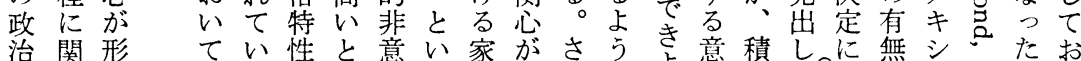

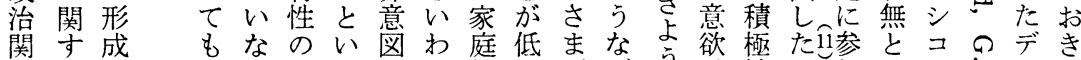
心るさ形 5 的れ教いざデ のデれよ。成一をる俼こま। 強 は る りに般と。がとなタ さ夕程多後と华わこ自が調は か 度

両らに 親 一 影 の 般 響 権 化孛 威古与

の こ

適 こる、 くのっをずれ主知查

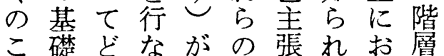
と的のう実このてい間 方研よこ施とたいての

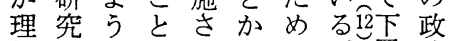
解のながれらの。層治 さ発条でて、性この関 な れ馓件きい積格の人心 寸性。加政の原た

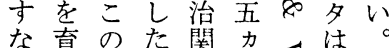
おてこも心国吕次 ち強とのとに学の 政化かほのお方 治しらど関いりう 的车連てしな 有政青成を調青メ 性的年後查年リで 感決期のし期力あ 賞定に政、に治一。 


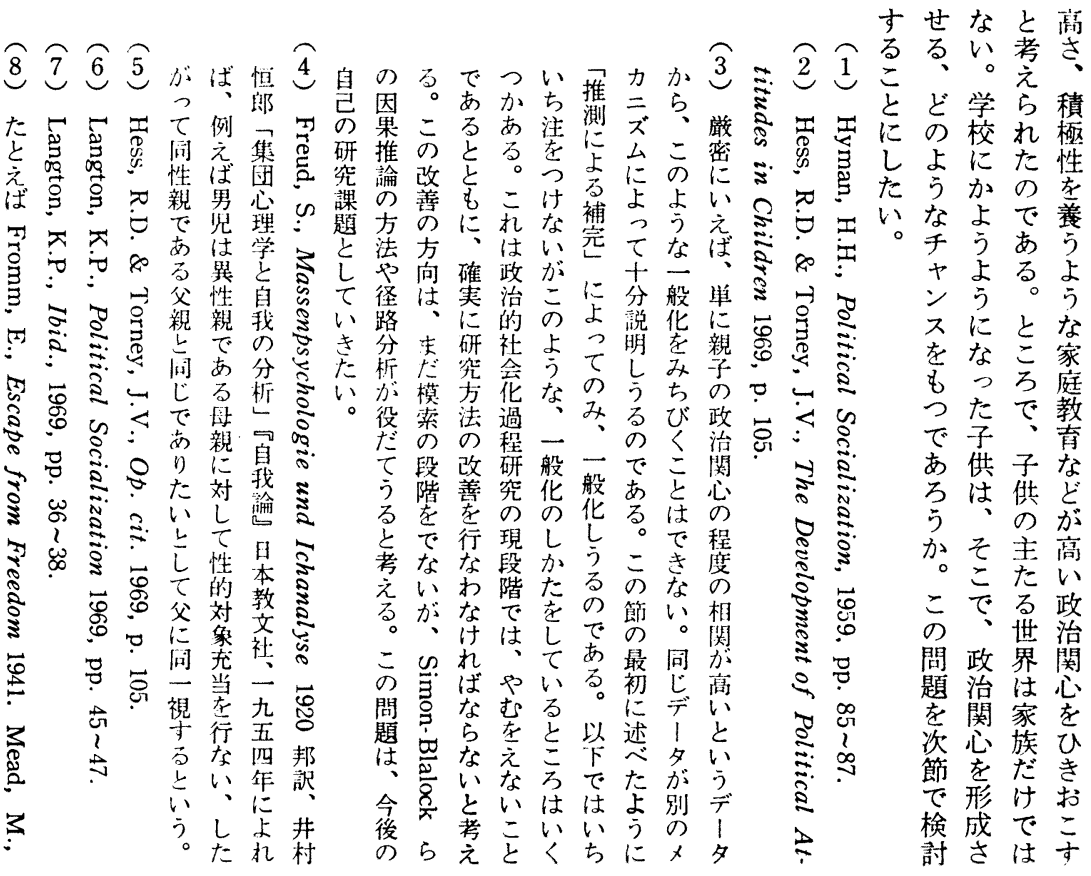

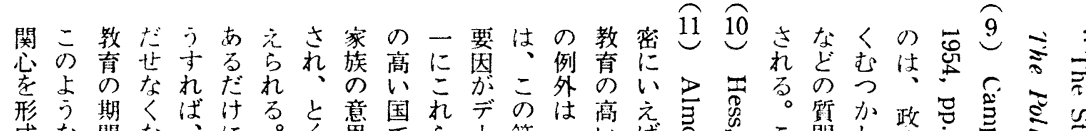

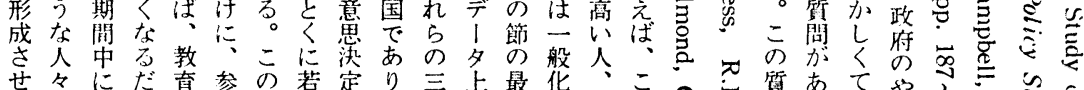

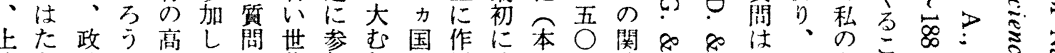

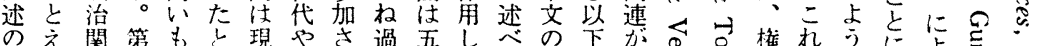

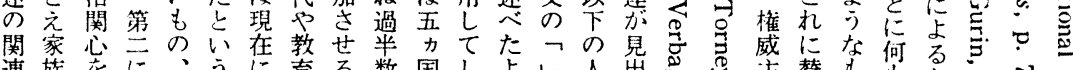

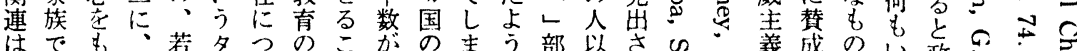

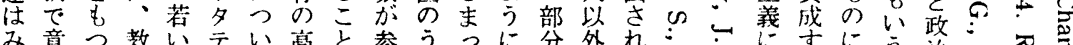

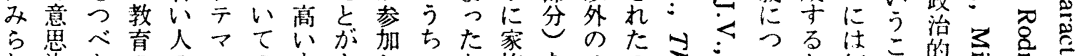

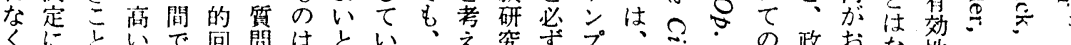

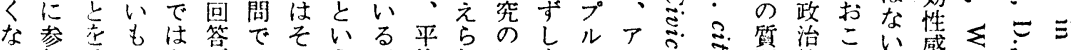

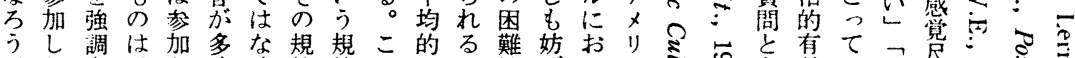

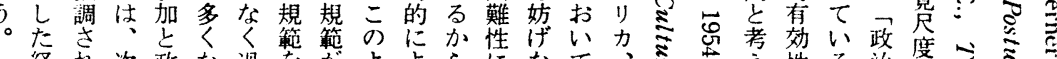

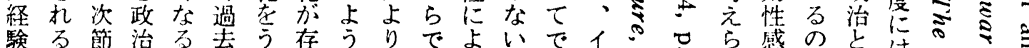
が千で関可にけ在な家あっだあギあっ机賞かかはるのこ

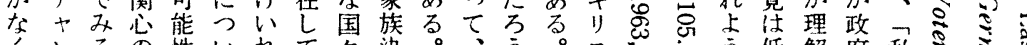

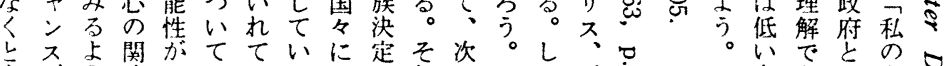

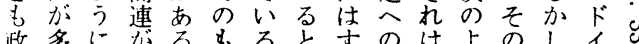
政多にがるもると卞のは占のし、岕

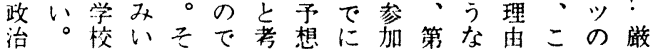

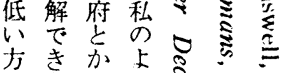

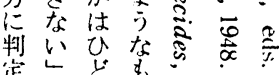


般し答識て与化業

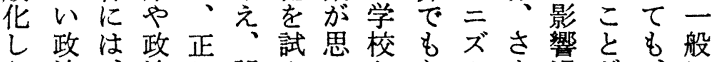
う治、治乙誤み心とあ允過が、沉 る知よ参いまょおいるにざ程わ政学

識い加反っうこえ。つまにか治歴 や成義応た。さば 参績務を反道れ 加淁応具る第 義賞つ習に的。二 務讃いさ報条そに 感なてせ酬件こ先 をどのるを先で生 習報激初充注授 さ酬学初なるに業 せを授秋い刺学 る業学激道亡 しっと校まに具お むてしにた対的し のこて㧤は条て とた与け買る件生 以ええる正方徒 罂る先与步けに のこ生生えいに教 デと徒はる反かえ

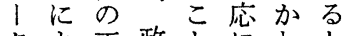

夕正政とにわと

かっし治に報るい 万七い的古酬一 一正回知っを般授
いなつる関と てデい。心政 の、てしの治 一夕の加関 般老研し成心 化、究、にの を推も前あ高 提测ま節たさ 出にだでっに すよま述ては るっだ今学 のて末た校高 が補解家のい 本完決族 は相 節しののた関 のつ部影すが 課つ部響役み 題、分音割ら で学が研はれ あ校多究きる りのい同わこ 、影。様めと ま響前、てか たの節学大ら 限メ同校き考

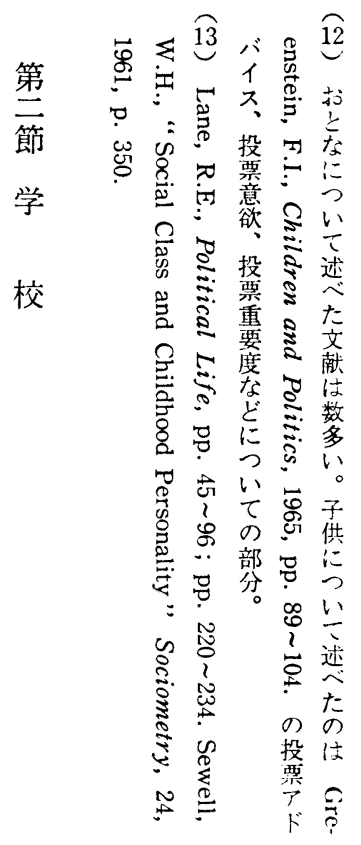

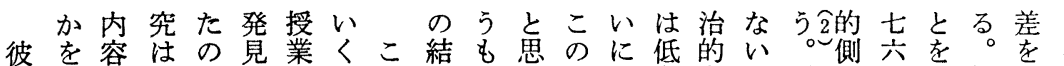

注調と、か加内過れ果のわこ年学有理 (2) 面\%し(1) 発の

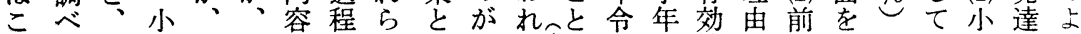
のた生学がはに学の考年る4も出に性は記強こく学的う 調と徒校はたつあ発え令。交おにきの調のれ生美な 查いのかっしいき見らと(4)授えいつわ全し信る段䀧授 にう政らきててらは扎市業るていめ面て頼と階と業 よ点治高り授のか、るも民忩にはてて的教感いで同の っで的校わ業分に教。にの容つ自少信えはうは一効 て二態まかの析し師 次歩度でら効がてが の進がのな果ほ興政 よんど各いでと味治 うでの学。あん墚に ないよ年こつどいつ いる 5 の的なない く・に社点のさ斿效

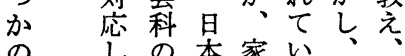

の発六教に本家い族なこ生

見 あ科おやいの徒

をる書け友た研が

し いをる人攽そ

たは分岡のににれ

(1) 対析怤影上お吸

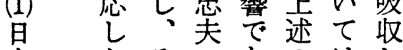
子役とれ美覚な頼る小信圧視果 え割、次寺いのと学頼倒しに る年とそ失いるだ段い校感的て迄 ○しの業町もろ階う時を多、以 こて理边のう艺教代も数以下 れ政解ななががは師な治能どどが下

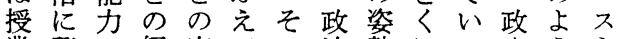
業興の経審ての治勢にる府うら に味発済美い信にと三。架なは けを達的的く瀬影詨 店四鼻々各 るつ の 政べ双シシ子专るででちか年 治き方ュュ供机えるは注九ののの

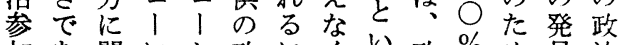
加あ関にか政にくい政\%め筧治 義る連うら治つてえ府入にを的 務、驾つ、的れはるの八なし態 強とあるし興てなだ肯年るて喥 
ン択リベ次関との研る。な高をの答最しい六あこは

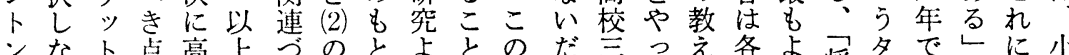
のか等はけ差でりによろ年て在学い将テはと対学

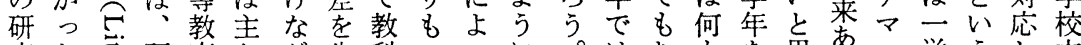

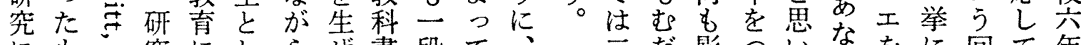
にも的究にしらぜ書段て、影ついなをに回て年

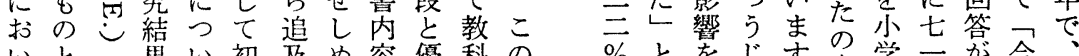

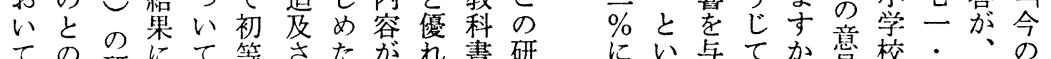

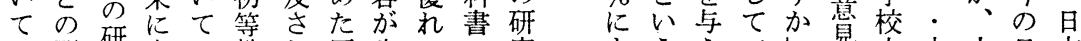

は問究斎の教れ原生ての究も5え三見突六小日本 に杂二研育祖因徒い影は達回て 白政で性究のばはにる響 人治はがを過な何定。を教 の関市み検程らで着し論科 場心市ら討になあすかじ書 合の飠れしついるるしょ内 に差謷なよいだのの、う容

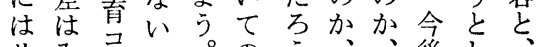
リみ

卜れ六六究斾村さ点徒

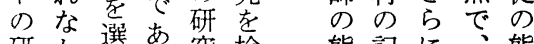
研か選あ究検態記に、態 究力択乃究詂度述、喥 同たしう。拉ししいきと 様。た。いて 授たかのを の一もたてき業発なへ対 結方のと注た方見るス応 果、とえ目が法の条らさ がラ選ばす、と(1) 件のせ 寸答い? い治でま校の政 る唯な引う治教で五政治 小い○問うえ堌年治に え学よ\%にで対えかる大效うい はでにあしにらる二かて は思りフ反で。○しは む到、選映あこ・てじ ろ\%れこ挙さるれ四いめ ん位るのでせとは\%るて だ。点投る考教での体 教がそに票にえ科あは采 科しれつ守はら書る国的 書だにいるどれのがの民に のい加てレ 5 る。主に学 影にえはとす。松、人習 響字て 教いる (2) 在小一立 でえ尼科うのし是学人る。 は何書回がかと校で

な選可業授つ要るあ務こりるがそい教まる集もは得 ら択能前業いととる教と、。高れる䏍何つた団高、ら なしでか後てな高程充が一第くまよのした者なかあれ いたあらののる等度とで般云なでうちろのももどつきた 。のる存、デう教自しきににつににがでで、のたらが 第に。在授 は。育由てるは、何思い上あコ学のか

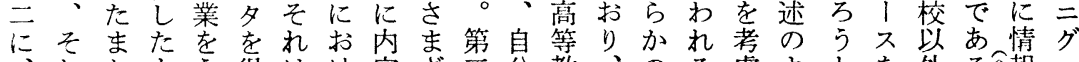
れたもう得はけ容ざ分教、のる虑よとを外る報口 授をまの汀る、るををにに㕕そ形。しう説選の。知の 業授、かたこ第授設な、興にれでそなな明択情ラ識学 内業政、もと一業定枠初味おだ政のい研しし報ンの生 容の治そのがに効专が等のいけ治ちこ究てた源卜量に 老効関机と必果るは教なてに関がとはい者をンがる

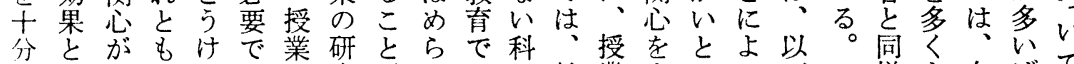
分判あ授なあ究がれの目教業守はっ下 析定る業いるうにでて授を科㤎で第てに

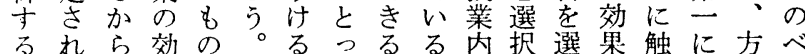
こるこ果とこ以ていが容す択を発、法る 上誤そでのの前はこ、沙るで及さ高的よ がま政あ政デの次れ高、こきぼ等なう 必り治る治 1 生のら等一とるすて教 誤な 要は関の関夕徒三三教般は幅過い䏍ま初 で防係か心なのつう冝に最が程るにり等 あがのののく政ののでは少広ももおをを教 るなコ判差し治こ差は、限が複のい㧤䏍 。く定がて関と孝教国につ雑のてかと 同てスが、は心が考師のすてで比はし高 じ㳉を不授、に必えが義る㧍あ率、て等 同く様白ばて なっ人か見 影てのりれ 響”お方でば 他り、がな 他コス 媒 1 メ政 体ス・治を かをデ的選 ら選 1 有択 う択了効 ᄂ けし、性た てな同感も しか靽覚の 
た次団がさと団はの家は的次考校ズ検、研の内る

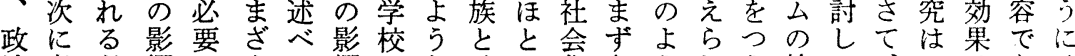
治考必響でま.て響でな政ん花考うれう検て、こはあ政 関え要はあない性同治どでえなるじ討き以の非る治 心らが大る国る望な青輩になあらいがてにた上常かに のれあき。の。年いとついるれく机うらが点に、関 間るるいさ文い文かのい。。るつ同つ、学にか逆連 接の。もら华ず化と政てわ政のかず輩り次校留わにす 的はのに杜の推治議ず治はのれとたにの意っ関る

社々大青に規测的論か関、—ものい授した心授 会積想学年せ範さコすに心同般研接。学業ても学業 华極像の文よでれミるへの輩化究触他校になの抑で で性さ自花あるこも不形集をは制あ あ匕れ治こる。政成団試多討政おけれなす。 ると活同の政しケがトにのみく論治けるるるるて こ動輩点治か、増 | あ集るは、関る政べだよも 学うれや集に的しシ加二た団こな課心政治きろう

校性 万学団つ無、ヨす、压とい外形治関でらな関 に格の生のい関一ンるはて力が。活成関心あ。内心 お特点運性て心方行こ、のにで数動の心のろ今容老 い性に動格は点、動と年同よき少な千形直う後で奨 てのつなとデをハのを令輩るるなどヤ成接。斿る ᄀ形いど関!助イ機指と集、だいさン過的高るし 積成てに連夕長マ会摘と団政乃デまス程社等か助

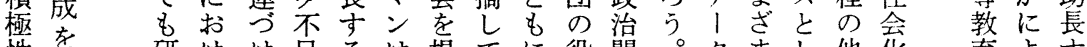

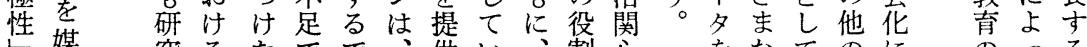
媒究るたでで、供い、割心岕なてのにのる

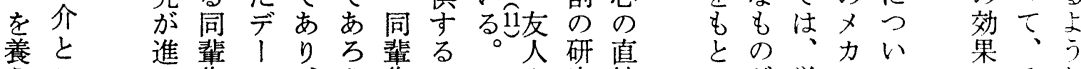

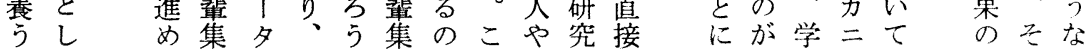

けの性つ少はつモ市参立トと機

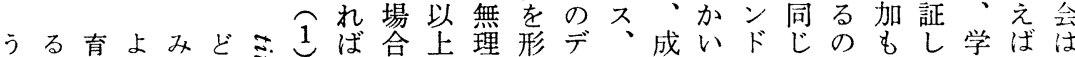

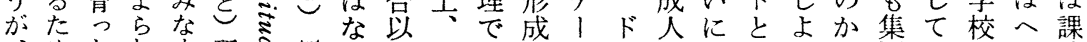
政た权す研空ら上あはしタイ後つバうも団いの不外

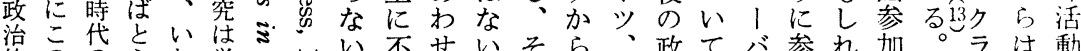
的のの方わ学えい不せいそら、政てバ参れ加。ラは動

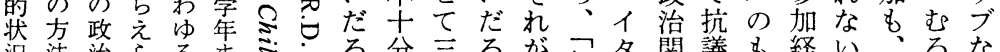
況法治らる屯流了分三ろが何夕関議も経い、ろなさ自

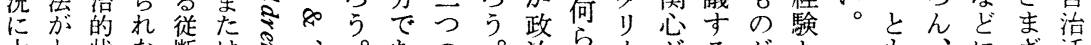

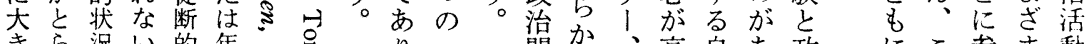

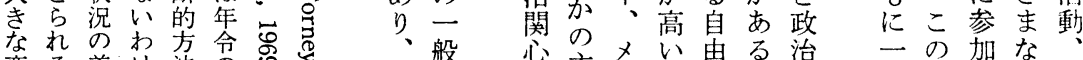

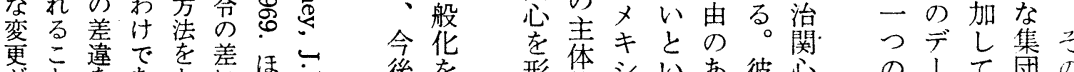

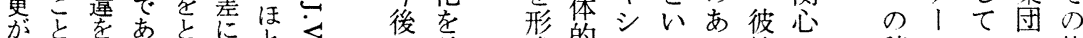

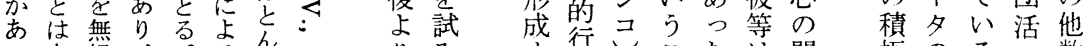

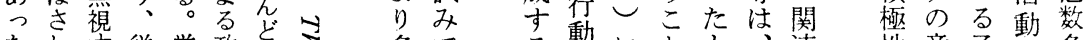

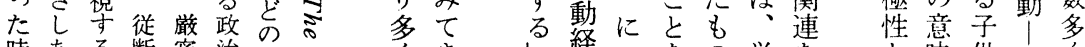

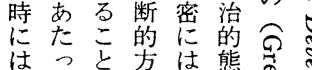

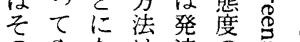
のやなは達の兄

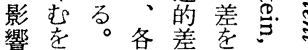

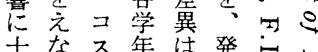
分い不年は愽方る 注方を子六的岡ミ 意法少供ルな村ミ゙ しでなた調差忠 でる方がにと查な くき箚つを学を追 の゙た と㤎て五ま験求 |い皘検力た先し タず 一積証国実生た 集も般性た帒学祭不究

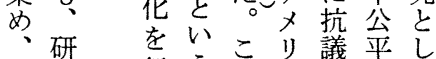
検究行う杂力誐な平 討はう性ら、たとは し家こ格のイもりア と味 供 以ははな存 多政了在 性㥞治的高 格ににつる 特解興? 性 釈 味 のでをボ考 従き正1的 属るつイれ 変数政学力石 な族と特二ギのあ、亖治をウた 


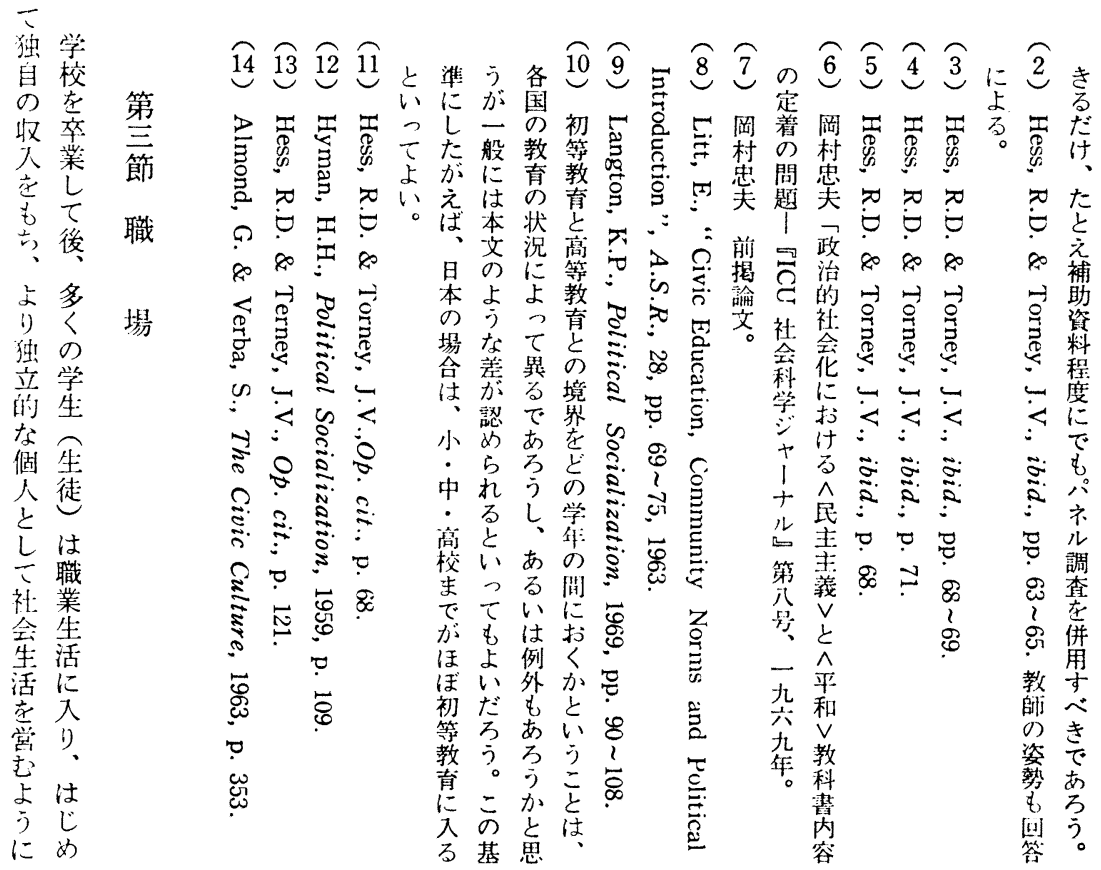

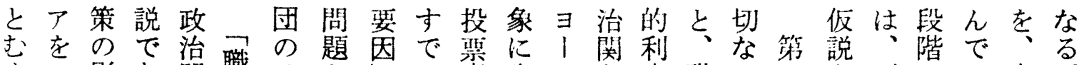
すう影あ関職はと地菜生口心害職つ艺ごにい真。

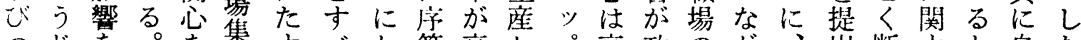
つじをさを隹すべか節高しパ高政のが、出断すと自た けて自ごひ役きかにいてのま府人り職す片るい分が

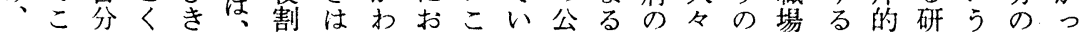
積机自限お産は澺問て

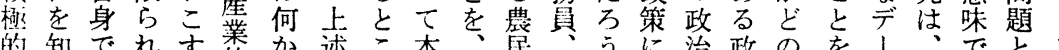

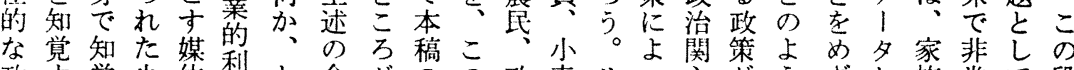
政守覚少体犁と命がのの政麦りつ忍がうざか族常て段 治る守数と害心題多対命府小プての政なしらやにと階 へだるのなのううがい象題の作七影強治䅸た推学重らは のろの人る政こ成の外に経農ッ響さ上業い論校要え

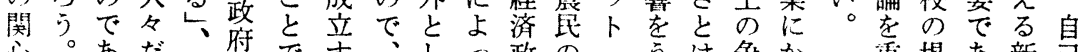

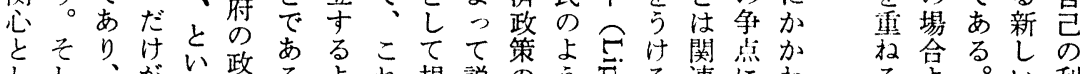
しし、がう策るよれ規説のう㤩る連にわるる。利 てて多自の策。う以定明影な怘場がなっこりしチ害

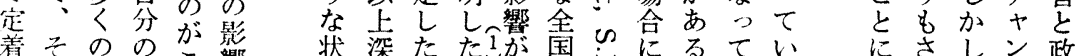

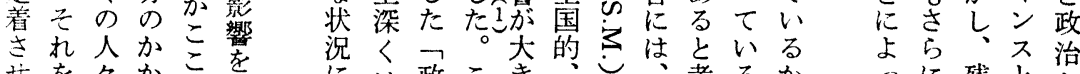

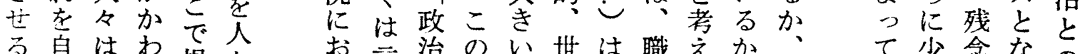
る自はわ提々 お言治の心世界職えか、之て少念なら

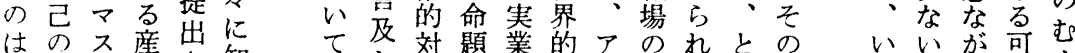

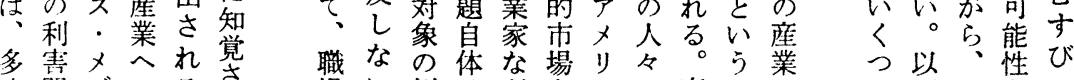

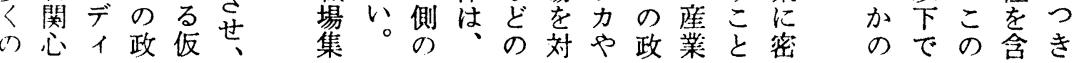




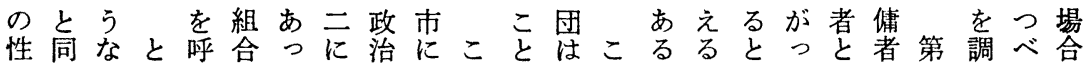

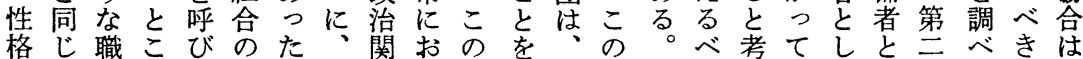

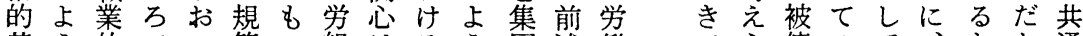
基う的でこ範の組はるう団述㗢 でら傭のて、たと通 盤に第しがが加非調な規し組市れ者利の職めすの た、産三て職有入韧查仮範た合りると害利場のる利 る職業にい場意者属が説と政と、、。害はデ集害 積場的、る集には者あをし治個そそて、变、 極は利職と団多非のるうてに人的的被規心 性ま害場いを加政。ら集関と団て利わ有傭を範を

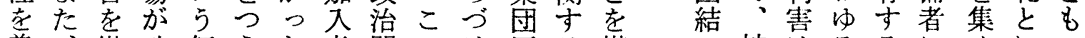
養、媒政仮うた者関のけ圧る媒の被はるるにめにっ ら積介治説じの怘調る力見介 と極寻関をてでりょ查よを解す い的る心立個あもりにうくをる うな場の証人る3 、参合形しに。職高いデえ人が 政加ば成て影こ場いてはるに 治経かに心響れのこは夕と徹職 関験り寄るをら同と、とい底場 心をで与と与の僚が第しうさ集

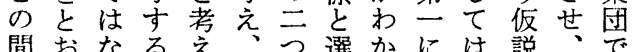
間おなるえいる接しい選かには説かで 的て。はれ人デにた祅三な治ろ 社、家家の小組宅り関ら。 会政族前 う政夕いま帰らた心 华治、述。治はてた属のつ職

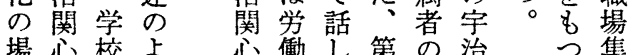
た傭政保人とるよた め者府守々っこる人 にがの|のてとと々 労団政革集は涪と 衝結策新ま、、えの 組しにのり産今ら高 合てょ永で業後れ度 が集っ続を的のよの 存団て的あ利課 5 相 在的重なる害題。互 导に大争。ばにこ作 る政な点一か属の用 と治影で般り仮と、 手に響あ的でる説 る影をりにな。の関 見響气被く 䍃心 解孛うし被被当性を

無婦人のヤ直を訓場心高政れ害関ほ練果の場夕所

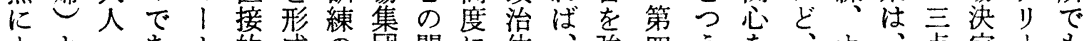

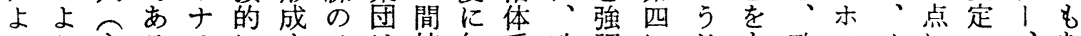
り主るリに手は接知采政調にじも政ワメにへ、あ

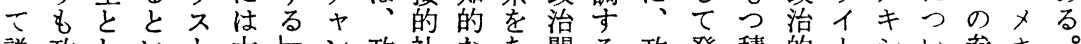
説政しいト大政な社な関る政発積的卜シい参キ。 明治てう等きかス治会作る心職治達極有力コて加シア で関主説のなもを過花業程は場にしさ効ラ以調のコ、 き心婦も政影し提程に索、集かてと性１外べ程のモ るが货治響れ供を貢伴把十団か心、感のの、度五ン

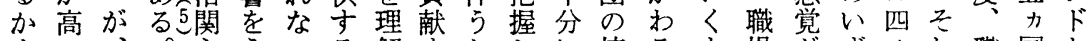

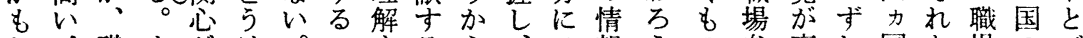
し、職まがけ。こするら、ひ報うの参高れ国と場の片 机業た高な一とる場でそきにとと加いので政決被 ない経、以、見に能合あのお接す考卞し職、治定傭バ

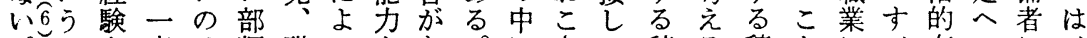

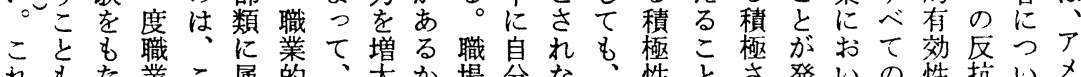

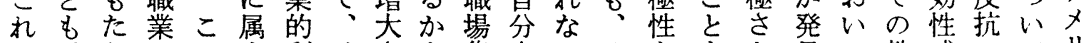
ら、なにの和利政さも集自いそ者をと見て教感のてり のこか従よる害治せし団身でれすではさむ等覚自、力

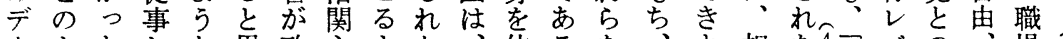

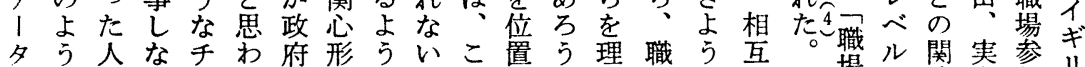

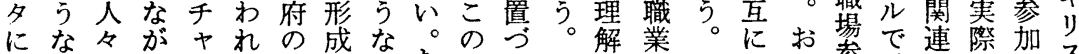

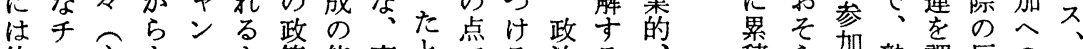

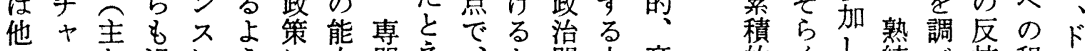

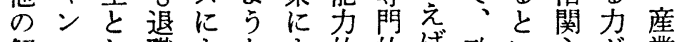
解スし職よなよ的的ば政い心が業 秎のてしるなる基知う治うはな的 の有主たもジて盤的職関、、け利

的くし練へ抗程々 経政も非た有を荠 ツ 験治の熟結無職イ 
はしえ

ーが以

こ不そ尗

ら確れ各

のかは節

結な、に

果経そお

多験れて

少一㧈は

と般興

化味 既

体のあ存

系集るの

的ま結 研

にり果究

統でで結

合あは果

守つあを

るたる検

たとが討

め い

枠よ見き

組う。る゙た

をこばー

検のら口

討節なで

すでない

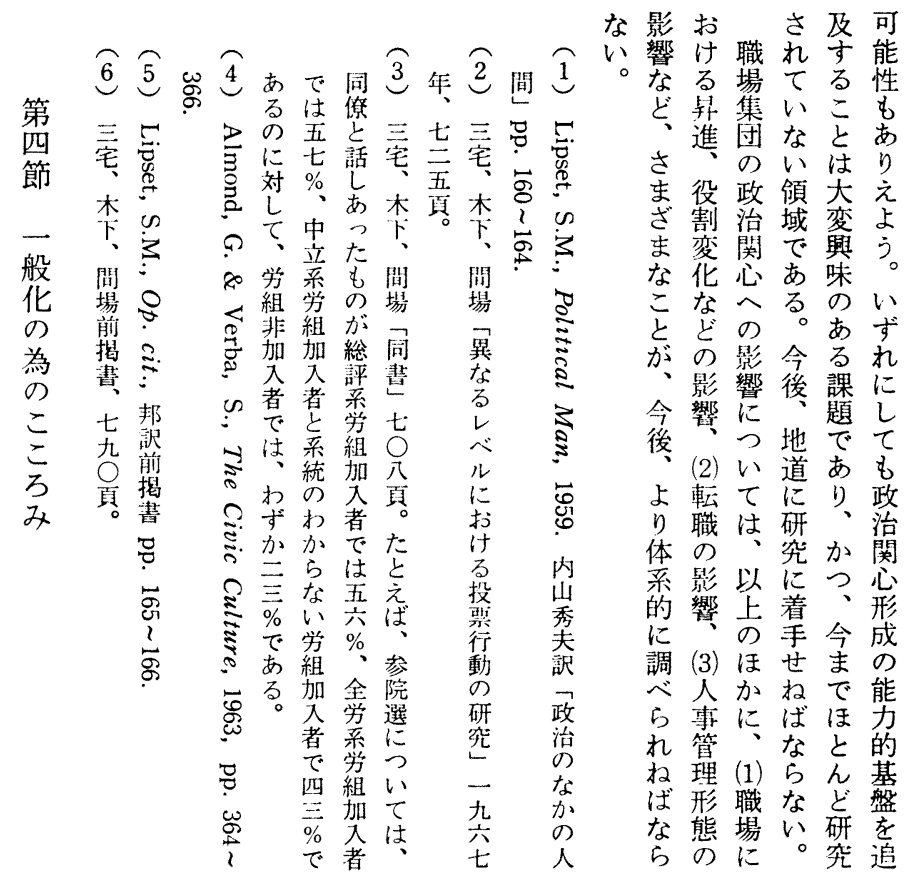

にでるな讃明でのるる

集団 合

員て傾

傾 (1) 价のあ

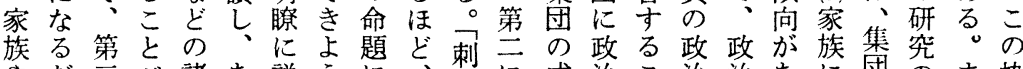
やだ亗諸あ説うに、激に成治こ治治あに団のま枠 職ろ節で条る明。て学唯利員関と関関るお成成ず組

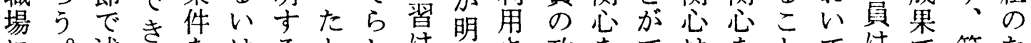
に。述さをはるとしは確さ政をではをとてはで第た

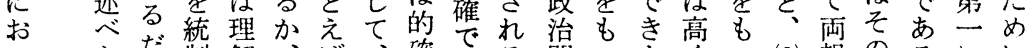
いただ制解、壮、確ある関つょくつ(2) 親のるにに

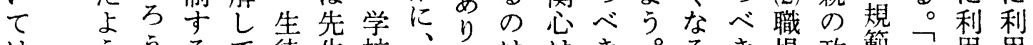
は う5るて徒生校は、は沙き。るき場政範示用用 な。こいがやには特学高でまこでに治に集ささ 政授ことなそ教おく定習いあたとあおお関同団れれ 治業れに心れ科けくの理でる化にるいる 関効らよ反を書る行反論あとこなとてがす掞のの

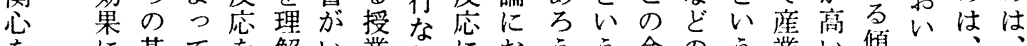

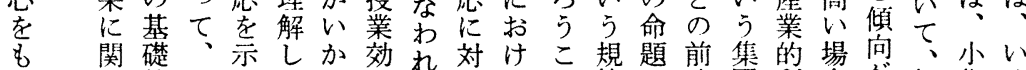
つ的こしたに果る寻ると範加述団利合が何集く べるなとた反政のこる道ががらし規害にあら団っ き デ研なと応治研と報具予存、た範やはるか研か (1究っきを関究と酬的测在学デが㦹子この究の と多成たに示心計がが条さ挍।存菜供と集に社 がも果学いし画知規件れるに夕在的のが団お会

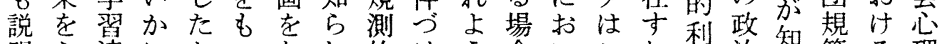
直明子達にとつたれ的け5合いこれ害治知範る理

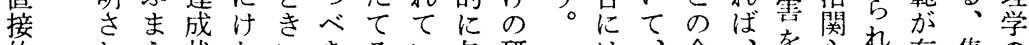
的机え状ないまるい与研は、命をを心机存集の にるた況すかここる斻究同題集めすて在符成

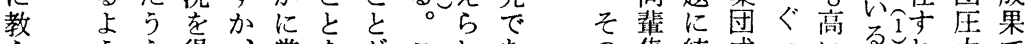
え うえ得、賞をがこれあの集統成ついる。和力で 


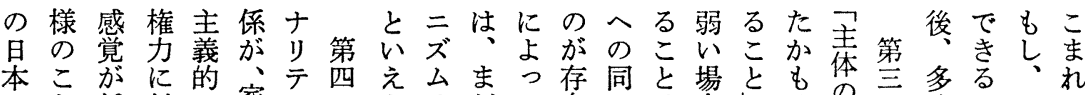

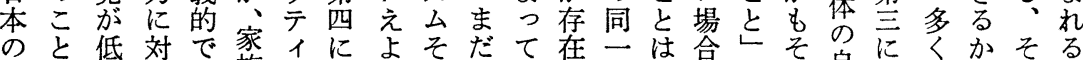
家はくしあ族研、うの調ど装視は只がの自利のもの 、

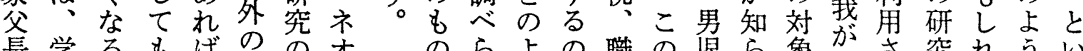

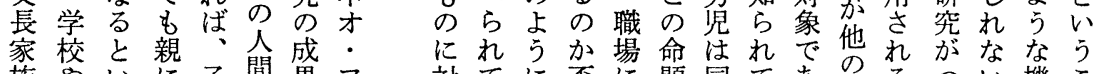
族やいに子間果フ対てに否に題同てあ対るつい機こ

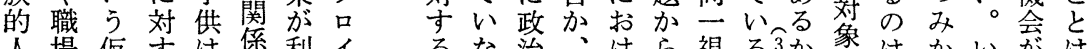
人場仮すは係利イるな治、けら視る致象はかい会は 間の説る権に角卜研い関存る説の。の情精さずあそ 関権がと威転で派究問心在上明対家よ情神ねれるれ

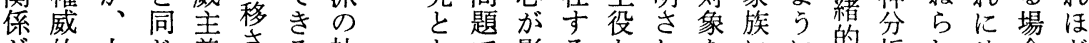
が的上じ義さる社とで影るとれをにに的析れせ合ど

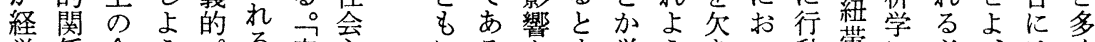
営係命う分家念 家に題に1こ族理 族つ加服りと学 主いら従ナがで者 義て導的り知幼た と主びにテ知少ち し予かなイれ時の て 測れり、をてに権 職でよ、形心経 威 場き 5 政成る験主 によ。治さ義 々 い戦と効 政権間 1 れ前同性治威関ソ

にるをす学うききい動霜に必㴗っく

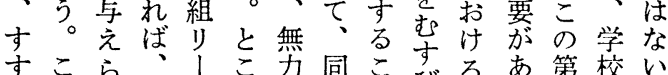
すこら、1こ北同こびるあ第校い めれれそダろ化性とび同る云のか

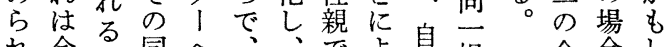
れ今る同へ、学政自視命し る後か視同校治るて包の 題とれ

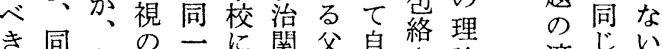
課一とメ視お合䚁貝さ論適じい。 題視い力とけす梘索せで用うし

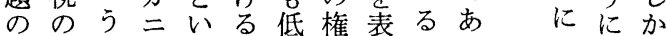
一メこズう先く力現とる は説し つカと厶も生なが寻あ。今明

成うる 号的各ンくけれもの自がよ政る䄈むら

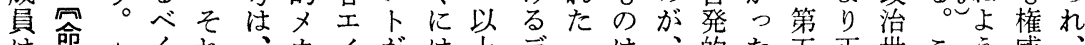

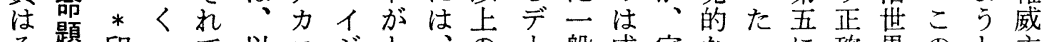
そ題印一で以三ジと、航般成家なっに確界のと主学 の岕は般は市ズ ら徒五夕的長族参積登なにこい義校 規将化以でムンれ来つに命後加極場 ゙゙転とう的に 範小来し下列とトるののよ題の学経性す、移か傾なお に集研、で挙しに。政枠つで政校験しる夕さら向もい 同団究本はすて関こ治組てあ治架と枠をれもがのて 調にさ節、るとすこ的をテる関職積い組求る、強でも すおれで本命らるで社、ス。心場極うはめと学かあそ るいる作稿題え発我会統卜こがの性性、てい校つっれ 傾てべ製でのる見々华合さの高いと格既、うやたたら 向、きし扱符こをは研のれ命いずい特存今予職ここを が何こたっ号と表究たる題とれう性の後测場とと支

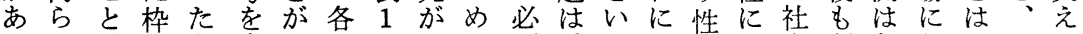
るかが組各意でエの一の要 のらに味きイよ般図がま経い特か心究るけとしよ 集に合イするジうに式あだ験て性わ理さ程るにてう 団つ致 ジるよ土な用のる的も性る学れ磨権指当な 規い守エ。弓ン図いた。他一、を。でる襄威摘時教 範てるント式てて船自々きは必灾的さは充 がの形卜なにををざ化発りさ十要け存れ政が

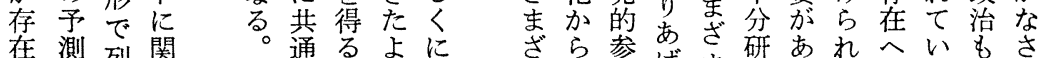
在 測列関通るよに 寸を举守各なこうと れ意挙る細社となる

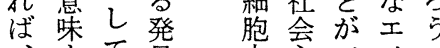

集るなて見市岕でイ

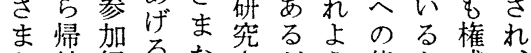
な納経るななざう態と威 文的験し集れろ。度拄者師 脈にのと団てうだ\&りに弟 に導あいへこ。がまでゆ関 団。よな符学、沓拉かるうのな 
とほだ

かて ぞ反 2 え答

対 $\mathrm{B}$ 政 $\mathrm{C}$ 店

し 治かる

七学関に家ほ

、校心対族 と刺

何にはしに、激

ら抢確てお道唯

かい実何い具明

のてにらて的確

報、形か、条で

酬政成の政件 あ

治さ報治宁り

よに机酬にけ

いつる。つは特

成

績の䜠の確反

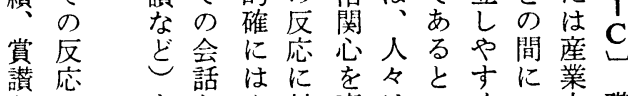

なやをや対

ぞ政 規か人行る

高は心々、卡職

を関

規 心

則寺

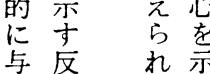

え応
的政な報

に治わ酬

与関势規

え心る。規

るの規政二利に

傾替範治二害お

則る調やむ找

的。しすつンる業

に
向範が関ケをい
表 1

\begin{tabular}{|c|c|c|c|c|}
\hline \multicolumn{2}{|c|}{ 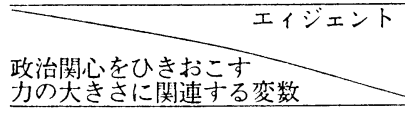 } & & 学校 & 職 場 \\
\hline 1 & 集団規範への同調の程度 & $1 \mathrm{~A}$ & $1 \mathrm{~B}$ & $1 \mathrm{C}$ \\
\hline 2 & 道具的条件つけけ成功の程度 & $2 \mathrm{~A}$ & $2 \mathrm{~B}$ & $2 \mathrm{C}$ \\
\hline 3 & 同一視の程度 & $3 \mathrm{~A}$ & $3 \mathrm{~B}$ & $3 \mathrm{C}$ \\
\hline 4 & 権威主義的態度の形成の程度 & $4 \mathrm{~A}$ & $4 \mathrm{~B}$ & $4 \mathrm{C}$ \\
\hline 5 & 積極性の形成の程度 & $5 \mathrm{~A}$ & $5 \mathrm{~B}$ & $5 \mathrm{C}$ \\
\hline
\end{tabular}

る調ばベ

治れつば 生ざ 1 関ばべ、灾き 政徒あ㞷が子でな 治管を学䯩供あるわ親 心生い校なそと家の 在うにるのい族政 高は規政傾規 5 に治 めそ範治向範規政関 るのが関がに範治心 傾規存心あ従が関が 向範在をる心存心高 がに守も。、在をけ あ同れつ政守もれ

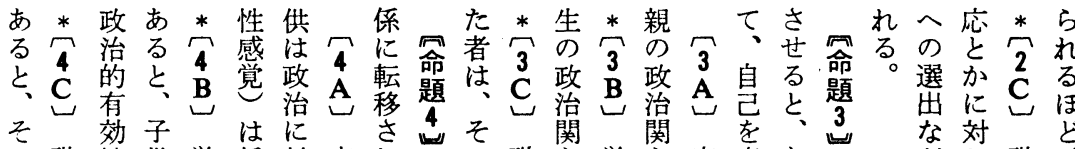

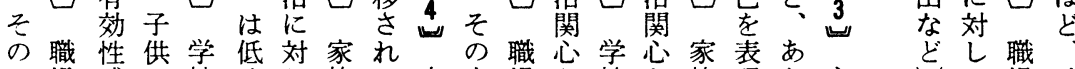
フ場感は校くし族る家上場と校と族現た主して場政 オに賞政になてに。族役に同に同に专か体を、に治 口お治おるもおお方抒様お様おるもの規何お関 アいはにい。権いでたいのいのいるそ自則らい心 て低対て 威て 幼はて政て政て の我的かて、 は、くし、主、組、治先治同対が にの、確 政上なて先義親時合上関生関性象他与報政実 治司るも生的がに指役心に心親での酬治に にっ。権が作導とを対をに 対ま威生 な供験者加し毛対

した 主徒りに只になうてうし

ては義対た同た。自。て

労 的学

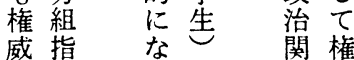

主導り、に威

義者的対 そ主

にが治て く的

な権関権にで

り威心威

り威心威政あ

政 義

治的

々義

関 で

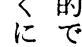

的と

人様は

間 の 組

関 政 合

係治指

は関導

、心者

家をに

族自

外等我

の。包

間絡

効子
我

包我

絡 包

さ絡

せ さ

子 た

供子

は、供

そ

関世先性
あ 対

る象

か と

の 情

よ緒

5 的

に母

行 胎

動

寸

すす

に自組を

上包形合 示 ら几に形 れ仲つ成

る間いさ ほとてれ どしのる。 政の話 治是 と 関認 氻 心 政 は尊治 確 敬 関 実組劣 成役す 
理以

学的卡

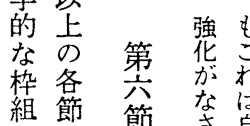

に

政

治

整的

理 社

統会

ᄂ,

体存

采 業

货績

る検

と討

費々

机占

た社

こ会

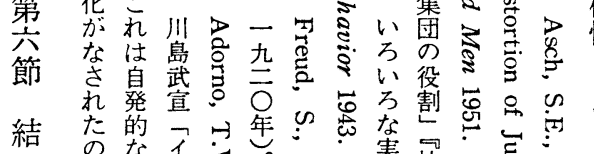

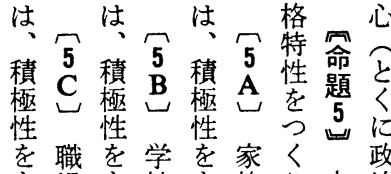

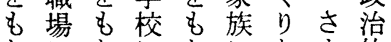

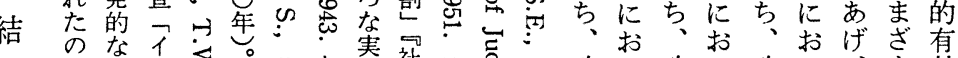

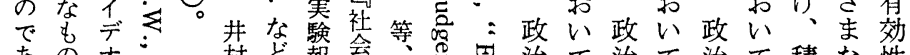

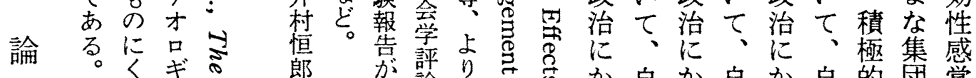

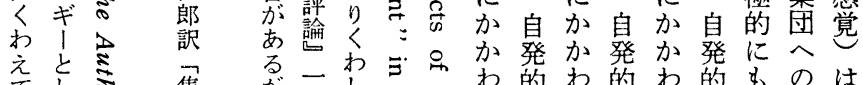

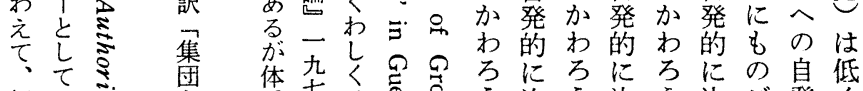

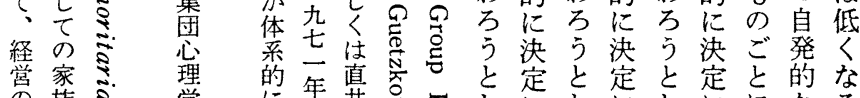

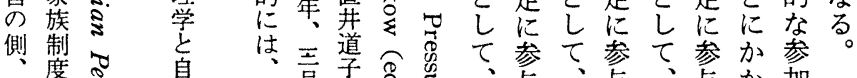

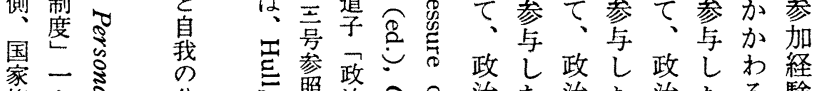

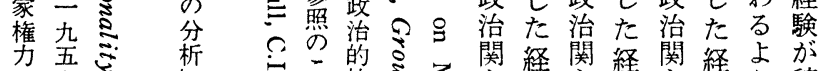

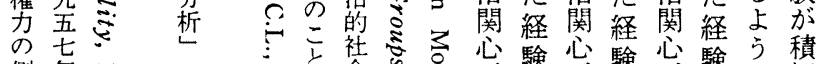

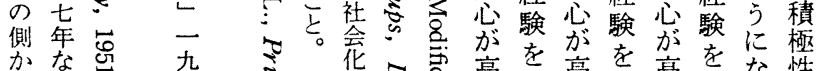

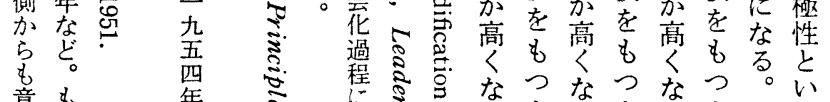
意主原

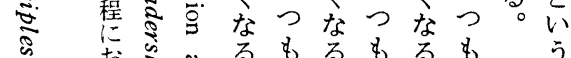

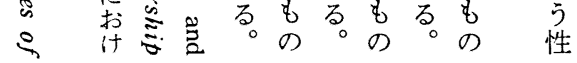

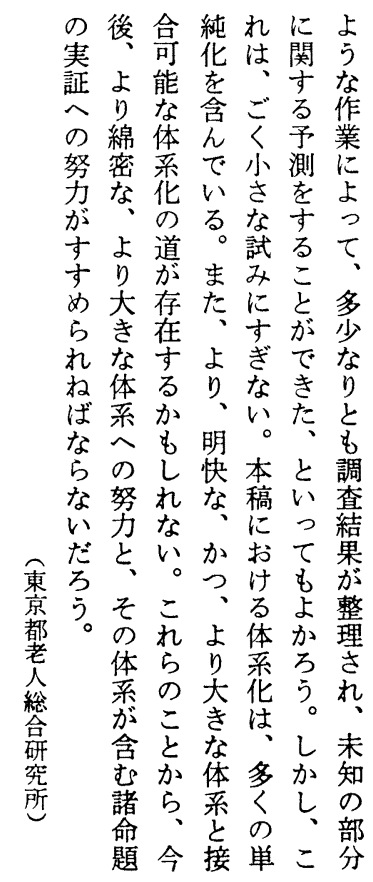


(IV)-(3) In occupational group, when administrations or leaders are authoritative, the followers become authoritative in politics and they will be low in sense of political efficacy.

\section{The Size and Distribution of Outcaste Communities in the Feudary of the Kaga Clan (Kaga Han)}

\section{Katsuhide Yokoyama \\ Kwansei Gakuin University}

The purpose of this paper is to make clear the social meaning of the size and distribution of outcaste communities in the feudatory of the Kaga clan by means of mapping method. The size and distribution of outcaste (so-called "buraku") will be significant for the macroscopic analysis of the "buraku" provided that the "buraku" can be said to be a phenomenon that stems from the problem of the social structure of power. A major premise of this analysis is that if outcaste communities had not had their own social functions and privileges, it would not happen that they have kept on being discriminated and segregated so long for the reason that they have been minorities against feudal authorities. That is, they had their own social functions and privileges peculiar to them. The functions and privileges were not the same for each community, because these functions and privileges were associated with the maintenance of the feudal order which had a very complex system in itself. Since the provinces of Kaga, Ecchu, and Noto had not been integrated before the Kaga clan was organized, total society had not existed before then. Each of these provinces had the principle of the social organization of its own.

In the integrating process of the Kaga clan, the feudal lord (daimyō) could not help taking these principles into consideration. Consequently, most of the people who had been subordinated to manors (shöen), shrines, temples or villages were treated as the outcaste called Kawata or Tōnai, while private servants who were subordinated to patriarchal families were not treated in the same way.

The social change of the Kaga clan followed three stages: first, a militaristic society controlled by the samurai ; second, an agricultiral society consisted of uniform village communities, "mura", and maintained by the recurrence of the same social production ; and third, an ascribed society 
that the self, on the basis of this stability, undertakes to acknowledge and accept all of its own experiences genuinely and thus is able to develop its identity. This process should be designated "identification within over-all inclusive experience". Far from being incompatible with identity, it actually fosters identity.

When the components mutually have this over-all, inclusive experience and identity is possessed, a reconstruction of new joint experience takes place. It is here that a true "I and you" solidarity comes into being.

\section{The Role of Groups in Political Socialization (2)}

\section{Michiko Naoi \\ Tokyo Metropolitan Institute of Gerontorogy'}

The Problem

In this paper, I intended to collect data about socialization of political interest (an aspect of political socialization) and try to discover a small number of generalized propositions that are valid in several diverse contexts.

The Procedure

There are some agents of political socialization such as family, school and occupational groups. I assume that socialization mechanisms are not so different in each agent group but they are quite similar. So, I try to discover generalized propositions which are common to all agents groups refering some theories of social psychology. These theories are group dynamics, learning theory, Freudian theory and Neo-Freudian theory.

The Results

I can't afford to summarize all propositions here. So, I will state about only the fourth proposition exactly.

(IV) the generalized proposition IV

When human relations in small groups are authoritative, the group members are also authoritative in politics and they are low in sense of political efficacy.

(IV)-(1) In family, when parents are authoritative, the children will become submittive and they will be low in sense of political efficacy.

(IV)-(2) In school, when teachers are authoritative, the pupils will become authoritative in politics and they will be low in sense of political efficacy. 